\title{
STUDIES ON THE ACTION OF HAGEMAN FACTOR: EVIDENCE THAT ACTIVATED HAGEMAN FACTOR IN TURN ACTI- VATES PLASMA THROMBOPLASTIN ANTECEDENT*
}

\author{
O. D. RATNOFF, $\dagger$ E. W. DAVIE and D. L. MALLETT $\ddagger$
}

(From the Departments of Medicine and Biochemistry, Western Reserve University and University Hospitals of Cleveland, Ohio)

(Submitted for publication November 17, 1960; accepted January 6, 1961)

Hageman factor is a component of normal plasma which participates in the early stages of blood coagulation (1). In freshly drawn blood, Hageman factor seems to be inactive, but contact with glass or certain other adsorbents changes it to an active form (2-8). The specific function of this activated Hageman factor has been puzzling. Several investigators have proposed that it reacts with a second clotting factor-plasma thromboplastin antecedent-to produce a clotpromoting substance $(5,9-12)$. In turn, the function of this clot-promoting substance remains to be explained, although its interaction with Christmas factor has been suspected $(11,13)$.

In the present study, techniques are described for preparing Hageman factor and plasma thromboplastin antecedent, each apparently deficient in other recognized clotting factors. The availability of these fractions has made it possible to examine their interaction. Evidence will be presented that activated Hageman factor converts plasma thromboplastin antecedent into a clot-promoting substance-activated plasma thromboplastin antecedent-by an enzymatic process. In turn, the clot-promoting substance probably acts enzymatically, although its substrate is not yet defined.

\section{NOMENCLATURE}

The terminology used to describe the clotting factors and hemorrhagic disorders has been summarized elsewhere (14). Briefly, Hageman trait refers to a familial disorder of the early stages of coagulation, first observed in a man without hemorrhagic symptoms (1). The plasma of patients with Hageman trait behaves as if it

* This study was supported in part by Research Grants H-1661(C) and RG-5303(C2) from the National Institutes of Health and in part by a grant from the American Heart Association.

$\dagger$ Career Investigator of the American Heart Association.

$\ddagger$ Postdoctoral Fellow, United States Public Health Service. were deficient in Hageman factor (1). Plasma thromboplastin antecedent (PTA) deficiency is a familial hemorrhagic disease in which the plasma appears to be deficient in PTA (15). Antihemophilic factor and Christmas factor are deficient in the plasma of patients with classic hemophilia and Christmas disease (or plasma thromboplastin component (PTC) deficiency], respectively.

The initial stages of the coagulation of plasma in vitro involve the interreactions of Hageman factor, PTA, Christmas factor and antihemophilic factor to form plasma thromboplastin. Platelets or certain phospholipids and calcium ions are also intimately concerned with the formation of plasma thromboplastin. In turn, plasma thromboplastin, in some undefined association with Stuart factor (Factor X), proaccelerin (Factor V), and calcium ions, converts prothrombin to thrombin. Thromboplastin may also be derived from tissues; tissue thromboplastin is optimally effective only in the presence of the precursor of serum prothrombin conversion accelerator (pro-SPCA or Factor VII). These interrelationships are demonstrated in Figure 1.

\section{MATERIALS AND METHODS}

Unless otherwise noted, all studies were performed with blood, plasma or plasma fractions which had been collected or prepared in silicone-coated tubes and had never wittingly been in contact with glass or similar clotpromoting surfaces.

$V$ cnous blood was drawn from the antecubital veins of normal subjects or from patients with various coagulative disorders, using no. 18 gauge needles coated with Arquad-2C (Monocote-E, Armour) and glass syringes coated with silicone (G.E. Dri-Film SC-87).

Experiments were performed with blood obtained from 5 patients with Hageman trait and 3 with PTA deficiency. The five with Hageman trait included J.H., M.R. and T.R., who were Patients I, II and III in an earlier publication (1) ; V.S., a 35 year old woman: and T.W., a 12 year old girl. V.S. and T.W. each has a brother with the same defect. Only V.S. has had symptoms suggesting a bleeding tendency; she had vaginal bleeding during the early months of a pregnancy still in progress. The patients with PTA deficiency were M.W. and B.Y., two of the three patients described in Rosenthal, Dreskin and Rosenthal's original study (15), and G.P., whose case was reported by Todd, Panter and 


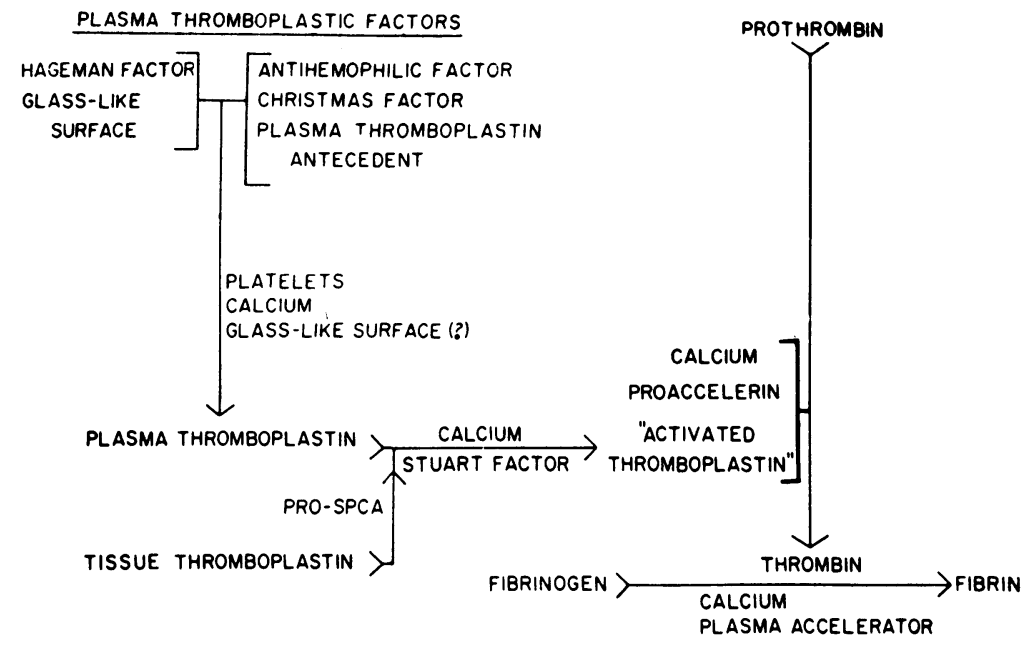

Fig. 1. A tentative OUtLine of SOME STEPS IN THE ClotTing PROCESS. Reprinted with permission of C. C Thomas, Springfield, Ill. (14).

Wright (16). M.W. and B.Y. were bled in New York and their frozen plasma carried to Cleveland, while G.P. was bled at different times in New York or Cleveland. The identity of the defect in the three patients with PTA deficiency has been confirmed by both Dr. Robert Rosenthal (17) and ourselves.

Platelet-deficient citrated plasma was prepared by an adaptation of the method of Conley, Hartman and Morse (18). Thirty $\mathrm{ml}$ of venous blood was withdrawn and discarded. Next, $30 \mathrm{ml}$ or more of venous blood was drawn through the same needle with fresh syringes. This blood was mixed with one-ninth its volume of $0.13 \mathrm{M}$ trisodium citrate and its cells were removed by centrifugation in silicone-coated Lusteroid tubes at 2,700 $\mathrm{G}$ for 15 minutes in an International SB size 1 centrifuge. The plasma was recentrifuged twice for 10 and 30 minutes, respectively, at $27,000 \mathrm{G}$ in an International high speed centrifuge. This platelet-deficient plasma was kept in silicone-coated Lusteroid tubes. It was then refrigerated in ice water and used within a few hours or stored at $-25^{\circ} \mathrm{C}$ until used. Unless otherwise noted, this plateletdeficient, citrated plasma, which had had no contact with glass was used in all the experiments to be described.

Aluminum hydroxide-adsorbed plasma is deficient in prothrombin, pro-SPCA, Stuart factor and Christmas factor. It was prepared by incubating $10 \mathrm{vol}$ of plasma with 1 vol of aluminum hydroxide gel for 3 minutes at $37^{\circ} \mathrm{C}$ in silicone-coated Lusteroid tubes. The mixture was then centrifuged for 5 minutes at $2,700 \mathrm{G}$. The supernatant plasma was usually used immediately, but its content of inactive Hageman factor and PTA was preserved by storage at $-25^{\circ} \mathrm{C}$ for several months or more. For different purposes, dilute or concentrated aluminum hydroxide gels were used.

Dilute aluminum hydroxide gel was prepared by diluting 1 part of a commercial suspension ${ }^{1}$ with 3 parts

\footnotetext{
${ }^{1}$ Provided through the courtesy of Cutter Labs.,
} Berkeley, Calif. of water, while concentrated aluminum hydroxide gel was undiluted Amphojel. ${ }^{2}$ The concentration of aluminum hydroxide gels, as provided by the manufacturers, is expressed in terms of aluminum oxide. The dilute aluminum hydroxide gel contained 0.6 per cent and the concentrated gel 4 per cent aluminum oxide; the latter also contained small, unspecified quantities of glycerin and sodium benzoate.

Barium sulfate-adsorbed serum is deficient in prothrombin, pro-SPCA, Stuart factor and Christmas factor. It was prepared by incubating venous blood for 4 hours at $37^{\circ} \mathrm{C}$ in Pyrex tubes. The serum was then separated by centrifugation, incubated for 20 hours at $37^{\circ} \mathrm{C}$ and stored at $-25^{\circ} \mathrm{C}$. Prior to use the serum was adsorbed for 10 minutes at room temperature with 100 $\mathrm{mg}$ of powdered barium sulfate (Baker) per $\mathrm{ml}$. After centrifugation the adsorbed serum was used within a few hours.

Heated plasma was prepared by incubation in a water bath. The temperature was determined by immersing the bulb of a silicone-coated thermometer in the tube of plasma or was estimated by immersing a thermometer in a similar tube containing water and heated simultaneously in the same section of the water bath.

Ammonium sulfate fractionation of plasma was performed in silicone-coated Lusteroid tubes by the addition of ammonium sulfate solution, saturated at $4^{\circ} \mathrm{C}$ and neutralized by the addition of $10 \mathrm{ml}$ of concentrated ammonium hydroxide per $\mathrm{L}$. The mixture was stored at $4^{\circ} \mathrm{C}$ for 1 hour or more and centrifuged for 5 minutes at $2,700 \mathrm{G}$. Each fraction was reprecipitated a second time prior to testing. Each was then dissolved in a volume of buffer equal to that of the original plasma and dialyzed against buffer for 48 hours.

Carboxymethylcellulose-treated plasma was prepared by shaking $1 \mathrm{ml}$ of plasma with $75 \mathrm{mg}$ of carboxymethyl-

${ }^{2}$ Without flavor, furnished through the kindness of Wyeth Labs., Philadelphia, $\mathrm{Pa}$. 
cellulose for 10 minutes in uncoated Lusteroid tubes (ID $11 \mathrm{~mm}$ ) in a mechanical shaker. The carboxymethylcellulose was then removed by centrifugation at 2,700 $\mathrm{G}$ for 5 minutes. Carboxymethylcellulose, containing approximately $0.72 \mathrm{mEq}$ of acidic groups per $\mathrm{g}$ of cellulose, was prepared by the procedure of Ellis and Simpson (19).

Crude Hagcman factor, deficient in PTA, was prepared from plasma of patients with PTA deficiency. The plasma was adsorbed with dilute aluminum hydroxide gel to remove prothrombin, pro-SPCA, Stuart factor and Christmas factor; this treatment did not decrease the titer of Hageman factor appreciably. The plasma was then heated at $56^{\circ} \mathrm{C}$ for 0.5 hour; this process decreased the titer of antihemophilic factor and proaccelerin, and precipitated fibrinogen but did not usually decrease the titer of Hageman factor. However, some preparations lost as much as half or more of their activity after adsorption and heating.

The adsorbed, heated plasma was then diluted to twice its volume by the addition of $0.15 \mathrm{M}$ sodium acetate $(\mathrm{pH}$ 5.2) and sufficient $1 \mathrm{M}$ acetic acid to bring the plasma to $\mathrm{pH}$ 5.2. The acidified plasma was diluted with an equal volume of water so that it was now at 4 times the original plasma volume, ionic strength 0.075 and $\mathrm{pH}$ 5.2. It was next stirred at room temperature for 10 minutes with $75 \mathrm{mg}$ of carboxymethylcellulose for each $\mathrm{ml}$ of the original plasma, and centrifuged for 5 minutes at $2,700 \mathrm{G}$. The carboxymethylcellulose was washed twice with $0.075 \mathrm{M}$ sodium acetate buffer ( $\mathrm{pH} 5.2$ ) and eluted twice at room temperature for 5 minutes each time with a mixture of equal amounts of $0.067 \mathrm{M}$ sodium phosphate buffer ( $\mathrm{pH}$ 6.8) and $1 \mathrm{M}$ sodium chloride. Each elution was done with a volume of eluting solution onehalf that of the original plasma. The two eluates were combined, recentrifuged to remove traces of carboxymethylcellulose, and dialyzed for 16 to 24 hours against buffer. The crude Hageman factor was stored in silicone-coated Lusteroid tubes at $-25^{\circ} \mathrm{C}$ until used.

Crude Hageman factor, prepared in this way, contained 1 per cent or less of the protein of the plasma from which it had been prepared. In most preparations it retained substantially all of the plasma's capacity to correct the abnormality in plasma deficient in Hageman factor. This crude Hageman factor was used in the experiments to be described. Further purification was obtained by column chromatography, adsorbing crude Hageman factor onto calcium phosphate gel and eluting it with a gradient of equal parts of $0.05 \mathrm{M}$ and $0.5 \mathrm{M}$ sodium phosphate buffer at $\mathrm{pH}$ 6.8. Still further separation from other proteins could then be made by using phosphocellulose. Details of this purification will be published at a later date; preliminary data indicate a minimal purification of about 1,000-fold, compared with the plasma from which it was prepared, although the significance of such comparisons is made difficult by the nature of the assay system.

Crude plasma thromboplastin antecedent, deficient in Hageman factor, was prepared in the same way as crude
Hageman factor from the plasma of patients with Hageman trait. The plasma was adsorbed with dilute aluminum hydroxide gel to remove prothrombin, pro-SPCA, Stuart factor and Christmas factor. This adsorption usually resulted in a decrease in the plasma's PTA activity of 75 to 80 per cent. The adsorbed plasma was then heated at $56^{\circ} \mathrm{C}$ for 30 minutes to precipitate fibrinogen and to decrease the titer of antihemophilic factor and proaccelerin. Plasma heated at $56^{\circ} \mathrm{C}$ had only about one-fourth or less of its original ability to shorten the clotting time of PTA-deficient plasma. However, when plasma was successively adsorbed with dilute aluminum hydroxide gel and heated at $56^{\circ} \mathrm{C}$ for 30 minutes, the loss of PTA activity was no greater than when either procedure was performed separately, so that adsorbed, heated plasma retained one-eight to one-fourth of its corrective capacity for PTA-deficient plasma.

The adsorbed, heated plasma was then adsorbed with carboxymethylcellulose, and crude PTA was eluted in the same manner as Hageman factor. This fraction contained about 1 per cent of the protein of the untreated plasma, but because of the losses in the initial steps of preparation represented only a 10 - to 20 -fold purification of activity; again, the nature of the assay makes an estimate of the degree of purification hazardous. Additional purification of this crude PTA could not be achieved, for reasons to be discussed in Section VII of Results.

A fraction of plasma that inhibits actiz' Hageman factor and active plasma thromboplastin antecedent was separated from pooled outdated citrated plasma obtained from the blood bank. The plasma was adsorbed with concentrated aluminum hydroxide gel and heated at $56^{\circ}$ $\mathrm{C}$ for 30 minutes. The fraction of plasma soluble at 50 per cent saturation but insoluble at 70 per cent saturation with ammonium sulfate was separated by centrifugation for 5 minutes at $27,000 \mathrm{G}$. This fraction was dissolved in buffer, reprecipitated at 70 per cent saturation, and collected on Whatman no. 54 filter paper on a Buchner funnel. The precipitate was dissolved in $1 / 6$ vol of water, dialyzed overnight against $0.01 \mathrm{M}$ sodium acetate $(\mathrm{pH} 5.2)$ and the precipitate discarded after centrifugation. The supernatant solution was dialyzed against barbital-saline buffer; it contained the inhibitory activity, about fourfold concentrated as compared with the original plasma. Its degree of purification was not determined. In this state, the inhibitory property was stable for several months at $-25^{\circ} \mathrm{C}$; this preparation was used in the experiments described. Further purification was possible by precipitating the fraction soluble at 22.5 per cent saturation with ethyl alcohol at $\mathrm{pH} 7.5$ and ionic strength 0.063 , but insoluble at $\mathrm{pH}$ 5.6. However, this fraction was too unstable for further study. The inactivating property is also present in plasma fractions IV-1 and IV-4, as separated by Cohn Method $6{ }^{3}$

Diisopropyl fluorophosphate (DFP)-treated plasma or plasma fractions were prepared by incubation of the appropriate plasma and DFP (K. \& K. Labs., Long Island City, N. Y.) in barbital buffer in dialysis tubing at

${ }^{3}$ Ratnoff, O. D. Unpublished observations. 
$25^{\circ} \mathrm{C}$ for 1 hour, followed by dialysis against several changes of buffer at $4^{\circ}$. In some cases, the pure DFP was initially diluted in anhydrous isopropanol before the final dilution was made. As a control for the latter experiments, pure isopropanol was added to a similar plasma preparation to ascertain whether any of the inhibition observed might be due to the isopropanol. In no case did the amount of isopropanol used produce any inhibition.

Concentrations of Hageman factor, plasma thromboplastin antecedent, antihemophilic factor and Christmas factor were assayed by measuring the effect of the sample to be tested upon the recalcified clotting time of plasma obtained from individuals with congenital deficiencies of these factors $(20,21)$. Concentrations of prothrombin (22), proaccelerin (21), pro-SPCA (21) and Stuart factor ${ }^{4}$ (23) were estimated by published methods. To test for thrombin, $0.1 \mathrm{ml}$ of the sample was incubated with $0.1 \mathrm{ml}$ of bovine fibrinogen solution at $37^{\circ} \mathrm{C}$ overnight. In addition, the same mixture was incubated in the presence of $0.1 \mathrm{ml}$ of $0.025 \mathrm{M}$ calcium chloride, since this salt potentiates the action of thrombin. The solution of bovine fibrinogen, prepared commercially, was said to contain $300 \mathrm{mg}$ of coagulable protein per $100 \mathrm{ml} .^{5}$

The thrombin time (1) and prothrombin time (24) were measured by previously described techniques. Commercial acetone-dried rabbit brain (Difco) was used as a source of tissue thromboplastin. To test the effect of plasma fractions upon serum prothrombic activity, 0.1 or $0.2 \mathrm{ml}$ was pipetted into new Pyrex tubes. Sufficient venous blood was added to bring the volume to $2.25 \mathrm{ml}$, and each tube was then inverted twice over Parafilm (Marathon). The tubes were incubated for suitable periods at $37^{\circ} \mathrm{C}$, stirred vigorously with $0.25 \mathrm{ml}$ of $0.13 \mathrm{M}$ sodium citrate, and re-incubated for 30 minutes. The tubes were then centrifuged at room temperature for 15 minutes at $1,900 \mathrm{G}$, and the prothrombin content of the serum was measured by the method of Alexander (22). The prothrombin content was compared with that of samples of plasma of the same blood obtained from similar tubes to which $0.25 \mathrm{ml}$ of $0.13 \mathrm{M}$ sodium citrate was added before the addition of blood.

"Cephalin"-fortificd clotting timc, an adaptation of the partial thromboplastin time (25), was devised to test the effect of clot-promoting fractions upon the clotting time of normal or abnormal plasmas in silicone-coated tubes. Duplicate determinations demonstrated the unreliability of the recalcified clotting time in siliconecoated tubes unless coagulation was accelerated by the addition of traces of "cephalin." The test was performed by incubating 0.1 or $0.2 \mathrm{ml}$ of the fraction to be tested, $0.1 \mathrm{ml}$ of plasma and $0.1 \mathrm{ml}$ of a "cephalin"-calcium mixture in silicone-coated tubes at $37^{\circ} \mathrm{C}$. The tubes were tilted once a minute until clotting occurred. Duplicate

${ }^{4}$ Russell's viper venom for this study was furnished through the kindness of Burroughs, Wellcome and Co., Tuckahoe, N. Y.

${ }^{5}$ Bovine fibrinogen was provided through the courtesy of Warner-Chilcott Labs., Morris Plains, N. J. determinations usually agreed within 1 minute when the clotting time was 20 minutes or less and within 3 minutes when the clotting time was 30 minutes or less. The "cephalin"-calcium mixture, freshly prepared before each test, was composed of equal parts of $0.05 \mathrm{M}$ calcium chloride and a crude chloroform extract of acetone-dried rabbit brain (26), diluted from its stock solution 4,000to 8,000 -fold with buffer. The stock solution was stored at $-25^{\circ} \mathrm{C}$.

The effect of incubating crude Hageman factor with plasma thromboplastin antecedent was tested by incubating a mixture of $0.1 \mathrm{ml}$ of each, suitably diluted with buffer, in silicone-coated tubes for the time desired. The tubes were then chilled in an ice bath. Simultaneously, each fraction was incubated separately for the same interval, chilled, and mixed in the same proportions. One-tenth $\mathrm{ml}$ of PTA-deficient plasma and $0.1 \mathrm{ml}$ of the "cephalin"calcium mixture were added to each tube and the "cephalin"-fortified clotting time was measured in the manner described. Conditions were so arranged that all tubes were assayed for clot-promoting activity simultaneously.

Inhibition of the activation of plasma thromboplastin antecedent was studied by adapting the preceding technique. One-tenth $\mathrm{ml}$ of crude Hageman factor, diluted $1: 10$, was incubated in a silicone-coated tube for $10 \mathrm{~min}$ utes at $37^{\circ} \mathrm{C}$ with $0.2 \mathrm{ml}$ of the substance to be tested. Then $0.1 \mathrm{ml}$ of undiluted crude PTA was added and the mixture was incubated for 30 additional minutes, chilled, and diluted with $9.6 \mathrm{ml}$ of buffer. At the same time, 0.1 $\mathrm{ml}$ of Hageman factor was incubated for 10 minutes with $0.2 \mathrm{ml}$ of buffer and for 30 additional minutes with 0.1 $\mathrm{ml}$ of PTA. Then $0.2 \mathrm{ml}$ of the test substance and 9.4 $\mathrm{ml}$ of buffer were added to the mixture. The clot-promoting properties of the two mixtures were compared by measuring the effect of $0.1 \mathrm{ml}$ aliquots upon the "cephalin"-fortified clotting time of normal plasma. As controls, the test substances, the clotting factors, and a mixture of Hageman factor and PTA were assayed alone. The substances tested included $2 \mathrm{M}$ sodium chloride; soybean trypsin inhibitor (Nutritional Biochemicals) dissolved in buffer in a concentration of $1 \mathrm{mg}$ per $\mathrm{ml} ; \epsilon$-amino$n$-caproic acid (Mann), dissolved in water in a concentration of $0.3 \mathrm{M}$; and $0.02 \mathrm{M}$ trisodium ethylenediamine tctraacetic acid ${ }^{6}$ prepared by neutralizing a $0.1 \mathrm{M}$ solution of the disodium compound with sodium hydroxide to $\mathrm{pH}$ 7.3 and diluting it to $0.02 \mathrm{M}$ with 1 part of water and 3 parts of buffer.

The esterase activity of crude Hageman factor and of PTA activated by Hageman factor was tested upon a substrate of $0.02 \mathrm{M} p$-toluenesulfonyl-L-arginine methyl ester for 24 hours at $37^{\circ} \mathrm{C}$, using a previously published method (27). The concentration of Hageman factor in the enzyme-substrate mixture was one-tenth that of the plasma from which it was separated. The activated PTA had been prepared by incubating an equal volume of undiluted PTA and Hageman factor, diluted $1: 100$,

${ }^{6}$ Sequestrene $\mathrm{Na}_{2}$ supplied through the courtesy of Alrose Chemical Co. 
for 3 hours at $37^{\circ} \mathrm{C}$. This mixture was diluted 10 -fold in the enzyme-substrate mixture.

Centrifugations were at $2^{\circ} \mathrm{C}$ unless otherwise noted. Dialyses were carried out at $4^{\circ} \mathrm{C}$ in Visking No-Jax casings. Pipettes were washed in chromic acid; all other glassware was cleaned with Dreft. All assays were performed in duplicate in uncoated or silicone-coated Pyrex tubes (ID $8 \mathrm{~mm}$ ); the average clotting time is recorded in the tables or figures. The protein content of plasma or fractions of plasma was measured by the technique of Lowry, Rosebrough, Farr and Randall (28). Unless otherwise specified, the buffer used in these studies was composed of $0.025 \mathrm{M}$ barbital and $0.125 \mathrm{M}$ sodium chloride at $\mathrm{pH} 7.5$ (1).

\section{RESULTS}

I. The preparation of Hageman factor from PTA-deficient plasma. The distinction between PTA and the Hageman factor was originally made by observing that PTA-deficient plasma corrected the defect in plasma thought to be deficient in Hageman factor (1). Previously described preparations of Hageman factor, derived from pooled normal serum, were contaminated with PTA. The use of PTA-deficient plasma as a source for Hageman factor was therefore explored. PTA-deficient plasma appeared to contain normal amounts of Hageman factor, since it was as effective as normal plasma in shortening the recalcified clotting time of plasma deficient in this substance. The same PTA-deficient plasma retained its Hageman factor activity after it had been adsorbed with dilute aluminum hydroxide gel. A variable portion of Hageman factor activity, often as much as three-fourths, was removed by adsorption with concentrated aluminum hydroxide gel. Hageman factor could also be adsorbed virtually quantitatively onto carboxymethylcellulose, from which it could readily be eluted.

The corrective effect of PTA-deficient plasma for Hageman trait resisted heating at $56^{\circ} \mathrm{C}$ for 30 minutes. Heating PTA-deficient plasma at $60^{\circ} \mathrm{C}$ for 30 minutes destroyed virtually all of its Hageman factor activity.

PTA-deficient plasma, adsorbed with aluminum hydroxide gel, and heated at $56^{\circ} \mathrm{C}$ for $30 \mathrm{~min}$ utes, was fractionated with ammonium sulfate. Almost all Hageman factor activity was concentrated in the fraction soluble at 30 per cent saturation and insoluble at 50 per cent saturation with ammonium sulfate; a sharper separation could not be made by this technique. Small amounts of
Hageman factor-like activity were also present in the fraction insoluble at 30 per cent saturation, and in the fraction soluble at 50 per cent but insoluble at 60 per cent saturation.

Serum prepared from PTA-deficient blood was as effective as normal serum in shortening the recalcified clotting time of plasma deficient in Hageman factor. In contrast, serum prepared from blood deficient in Hageman factor had only traces of clot-promoting activity for plasma deficient in the same factor. In these experiments, the serum was first adsorbed with barium sulfate to diminish the concentration of other clot-promoting substances.

The various properties that have been described were given consideration in the preparation of crude Hageman factor from PTA-deficient plasma.

II. Properties of crude Hageman factor. Crude Hageman factor, prepared from PTA-deficient plasma in the manner described, corrected the abnormality in plasma deficient in this substance, On the other hand, it was virtually without effect on the recalcified clotting time or "cephalin"-fortified clotting time of PTA-deficient plasma (Table I).

Previous studies have localized the defect in Hageman trait to the earliest stages of clotting. The properties of crude Hageman factor are in agreement with this interpretation. It accelerated the coagulation of normal plasma in glass tubes, but its effect was more dramatic in silicone-coated tubes (Table II). Its clot-promoting effect was a double logarithmic function: a linear relationship could be plotted between the logarithm of its con-

TABLE I

The effect of crude Hageman factor upon the coagulation of abnormal plasmas

\begin{tabular}{|c|c|c|}
\hline \multirow[b]{2}{*}{$\begin{array}{l}\text { Concentration of Hageman } \\
\text { factor }\end{array}$} & \multicolumn{2}{|c|}{ Clotting time* } \\
\hline & $\begin{array}{l}\text { Hageman } \\
\text { factor- } \\
\text { deficient } \\
\text { plasma }\end{array}$ & $\begin{array}{c}\text { PTA- } \\
\text { deficient } \\
\text { plasma }\end{array}$ \\
\hline $\begin{array}{l}1: 10 \text { plasma concentration } \\
1: 40 \text { plasma concentration } \\
\text { Buffer control }\end{array}$ & $\begin{array}{r}9 \\
10 \\
>60\end{array}$ & $\begin{array}{l}>60 \\
>60 \\
>60\end{array}$ \\
\hline
\end{tabular}

* Clotting time of a mixture of $0.1 \mathrm{ml}$ each of crude Hageman factor deficient in PTA, platelet-deficient plasma and "cephalin"-calcium mixture. The crude Hageman factor was diluted with buffer. Clotting times were measured in duplicate at $37^{\circ} \mathrm{C}$ in silicone-coated tubes. 
TABLE II

The effect of activated Hageman factor and of spontaneously active plasma thromboplastin antecedent upon the coagulation of normal plasma

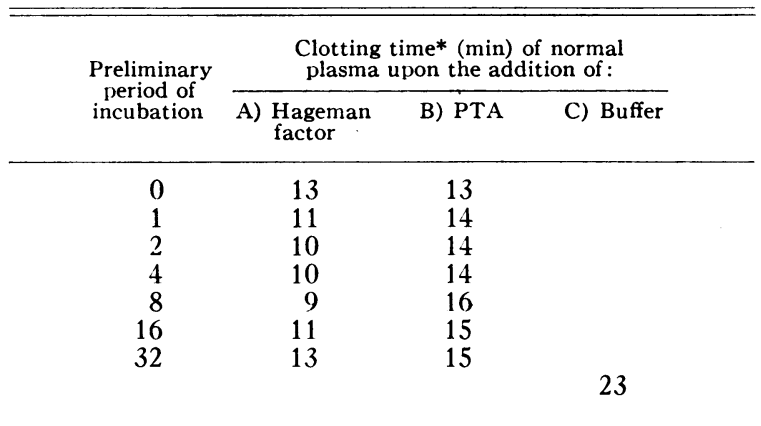

* Clotting time of a mixture of $0.1 \mathrm{ml}$ each of crude activated Hageman factor, deficient in PTA (at 1:100 plasma concentration) or spontaneously activated crude PTA, deficient in Hageman factor (at original plasma concentration) or buffer, normal plasma and "cephalin"-calcium mixture. The Hageman factor or PTA was incubated alone at $37^{\circ} \mathrm{C}$ in silicone-coated tubes. At intervals, the plasma was added to successive tubes. After 32 minutes, the "cephalin"-calcium mixture was added to all tubes and the clotting times were measured in duplicate at $37^{\circ} \mathrm{C}$.

centration and the logarithm of the clotting time of the substrate plasma.

The clot-promoting property of crude Hageman factor suggested that it had been activated at least in part during its preparation. The clotpromoting effect of this "activated" Hageman factor was increased by incubating it with normal plasma before recalcification. In one such experiment, small amounts of crude activated Hageman factor were mixed with normal plasma and incubated in silicone-coated tubes at $37^{\circ} \mathrm{C}$. At intervals, aliquots of this mixture were recalcified and the clotting time was measured in the presence of traces of "cephalin." Under these conditions, the clotting time of the mixture of activated Hageman factor and normal plasma gradually shortened (Table II, columns A and C). These experiments demonstrated that crude activated Hageman factor reacted with a component of normal plasma before the addition of calcium. After 8 minutes, the clotting time of the mixture gradually lengthened. The significance of this effect will be discussed later.

The clot-promoting effect of activated Hageman factor was apparently exerted at an early step in blood coagulation. Preparations of activated Hageman factor were devoid of detectable thrombin-like activity, since they did not clot solutions of fibrinogen even in the presence of calcium ions. They were without effect upon the one-stage prothrombin time of normal plasma. Nonetheless, they greatly increased the rate at which prothrombin was converted to thrombin during the coagulation of normal blood (Table III).

The increased prothrombin "consumption" which occurred in the presence of crude activated Hageman factor could not be attributed to its contamination with other recognized clotting factors. Preparations of Hageman factor were free of cletectable pro-SPCA, Stuart factor, proaccelerin, prothrombin and antihemophilic factor, and did not shorten the abnormally long prothrombin time of the plasma of a patient under treatment with Dicumarol. One undiluted preparation shortened the recalcified clotting time of plasma deficient in Christmas factor from 70 to 41 minutes; in contrast, normal plasma, diluted $1: 40$, shortened the clotting time of the same plasma to 7 minutes. Hageman factor was thus rot contaminated with any appreciable amount of other known components of the clotting system.

At least three hydrolytic enzymes found in human plasma-plasmin, thrombin and the esterase derived from the first component of complementdigest $p$-toluenesulfonyl-L-arginine methyl ester. Crude activated Hageman factor did not hydrolyze this substrate, distinguishing it from these enzymes. However, the preparation did contain plasminogen, since fibrinolytic activity appeared upon the addition of streptokinase.

III. The effect of carboxymethylcellulose upon blood coagulation. Contact with glass or certain other adsorbent surfaces accelerates the clotting of normal plasma. This clot-promoting activity can be detected only in plasmas containing Hage-

TABLE III

The effect of activated Hageman factor upon serum prothrombic activity

\begin{tabular}{cc}
\hline \multicolumn{1}{c}{ Test substance } & $\begin{array}{c}\text { Prothrombic } \\
\text { activity* }\end{array}$ \\
\hline & $\%$ \\
Activated Hageman factor & 5 \\
Buffer & 35
\end{tabular}

* Serum prothrombic activity of a mixture of $0.1 \mathrm{ml}$ of crude activated Hageman factor (deficient in PTA), diluted 100 -fold with buffer, or buffer, and $2.15 \mathrm{ml}$ of whole blood, incubated at $37^{\circ} \mathrm{C}$ for 30 minutes in Pyrex tubes. 
man factor. Contact with these adsorbents seems to transform Hageman factor from an inactive to an active form in which it can accelerate clotting. Evidence has been presented that the crude Hageman factor used in the present study had been activated at least in part (Section II and Table II). Since its adsorption to carboxymethylcellulose was a step in the preparation of crude activated Hageman factor, the possibility was considered that carboxymethylcellulose, like other adsorbents, accelerates the clotting of normal plasma. To test this, normal plasma was agitated with carboxymethylcellulose and then tested for its clot-promoting effect on untreated plasma (Table IV). This experiment demonstrated that agitation with carboxymethycellulose induced clot-promoting activity in normal plasma.

$I V$. The preparation of PTA from Hageman factor-deficient plasma. No satisfactory method of preparing PTA from normal plasma has been described. The plasma of patients with Hageman trait contains PTA activity. The properties of such plasma were studied to determine the conditions needed to prepare PTA that was deficient in other recognized clotting factors.

Plasma deficient in Hageman factor shortened the recalcified clotting time of PTA-deficient plasma to the same degree as did normal plasma, as if it contained normal amounts of PTA. Similarly, serum obtained from patients with Hageman trait shortened the clotting time of PTA-deficient plasma, but serum prepared from PTA-deficient blood was without any corrective effect. Each serum had first been adsorbed with barium sulfate to remove other clot-promoting substances. PTA activity was also present in oxalated Hageman

TABLE IV

The clot-promoting effect of carboyxmethylcellulose

\begin{tabular}{lc}
\hline \multicolumn{1}{c}{ Test plasma } & Clotting time* \\
\hline & $\min$ \\
Carboxymethylcellulose-treated plasma & 24 \\
Control plasma & $>300$ \\
\hline
\end{tabular}

* Clotting time of a mixture of $0.1 \mathrm{ml}$ each of the test plasma, untreated plasma and $0.05 \mathrm{M}$ calcium chloride. The test plasma was prepared by agitating $1 \mathrm{ml}$ of normal plasma for 10 minutes at room temperature in a Lusteroid tube containing $75 \mathrm{mg}$ of carboxymethylcellulose, which was then removed by centrifugation; the control plasma was similarly treated except that the carboxymethylcellulose was omitted. Clotting times were measured in duplicate at $37^{\circ} \mathrm{C}$ in silicone-coated tubes. trait plasma which had been stored at $-25^{\circ} \mathrm{C}$ for more than 4 years.

Adsorption of normal plasma or plasma deficient in Hageman factor with dilute aluminum hydroxide gel usually resulted in a decrease in its PTA activity of 75 to 80 per cent. When the adsorption was carried out with concentrated aluminum hydroxide gel, nearly all of the corrective effect of these plasmas was lost. A second adsorption with concentrated aluminum hydroxide usually removed all but traces of PTA-like activity. Thus, this factor was more readily adsorbed from plasma by aluminum hydroxide than was Hageman factor. Attempts to elute PTA from aluminum hydroxide gel have been unsuccessful.

PTA could also be adsorbed onto carboxymethylcellulose; in this case, it could be eluted without obvious loss.

Normal plasma or plasma deficient in Hageman factor, heated at $56^{\circ} \mathrm{C}$ for 30 minutes, had only about one-fourth or less of its original ability to shorten the clotting time of PTA-deficient plasma. All activity was lost after incubation at $60^{\circ} \mathrm{C}$ for 30 minutes, and plasma, heated in this way, actually acquired clot-inhibitory properties. When plasma was successively adsorbed with dilute aluminum hydroxide gel and heated at $56^{\circ} \mathrm{C}$ for 30 minutes, the loss of PTA-like activity was no greater than when either procedure was performed separately. Normal plasma, treated in this way, still shortened the clotting time of plasma deficient in Hageman factor almost as readily as did untreated plasma. On the other hand, Hageman factor-deficient plasma, treated the same way, had no effect upon untreated Hageman factordeficient plasma. Such plasma was suitable as a starting material for the concentration of PTA, deficient in Hageman factor.

Maximal PTA activity was found in the fraction of adsorbed, heated plasma soluble at 40 per cent and insoluble at 50 per cent saturation. However, the degree of purification achieved by ammonium sulfate precipitation at this stage was not enough to be useful in purification.

Crude PTA, deficient in other clotting factors and apparently suitable for the experiments to be described, was prepared by methods derived from these observations.

$V$. Properties of crude plasma thromboplastin antecedent. Freshly prepared crude PTA, de- 
TABLE V

The effect of crude plasma thromboplastin antecedent upon the coagulation of PTA-deficient plasma

\begin{tabular}{lc}
\hline \multicolumn{1}{c}{ Test mixture } & Clotting time* \\
\hline & $\min$ \\
Hageman factor-deficient plasma, diluted $1: 20$ & 10 \\
Hageman factor-deficient plasma, diluted $1: 80$ & 13 \\
Hageman factor-deficient plasma, diluted $1: 320$ & 15 \\
Crude PTA, 1:20 plasma concentration & 14 \\
Buffer control & 18 \\
\hline
\end{tabular}

* Clotting time of a mixture of $0.1 \mathrm{~m}$ ! each of Hageman factor-deficient plasma or crude PTA (prepared from Hageman factor-deficient plasma) or buffer, PTA-deficient plasma, and $0.025 \mathrm{M}$ calcium chloride. The Hageman factor-deficient plasma and PTA were diluted with buffer. The clotting times were measured in duplicate at $25^{\circ} \mathrm{C}$ in Pyrex tubes.

rived from Hageman factor-deficient plasma, shortened the clotting time of PTA-deficient plasma in Pyrex tubes (Table V). On the other hand, the same fraction was either without effect on normal plasma or was slightly inhibitory (Table VI). The significance of this inhibitory activity is not yet clear. An inhibitor of the clotpromoting properties of glass and other adsorbents has been found in Hageman factor-deficient plasma $(1,4,10,29)$, but its identity with the inhibitor in crude PTA is uncertain.

Crude PTA did not seem to be contaminated with other recognized clotting factors. It lacked thrombin-like activity and did not influence the one-stage prothrombin time of normal blood. It did not influence the conversion of prothrombin to thrombin in whole blood, as tested by mixing $0.2 \mathrm{ml}$ of an undiluted preparation to 2.15 $\mathrm{ml}$ of whole blood and measuring the prothrombin remaining after 20 minutes. It contained no measurable pro-SPCA, Stuart factor, proaccelerin, prothrombin, antihemophilic factor or Christmas factor, and was without influence on the prothrombin time of the plasma of a patient under treatment with Dicumarol.

TABLE VI

The effect of crude plasma thromboplastin antecedent_upon the coagulation of normal plasma

\begin{tabular}{cc}
\hline \hline Test mixture & Clotting time* \\
\hline & $\min$ \\
Crude PTA & 23 \\
Buffer control & 16
\end{tabular}

* Clotting time of a mixture of $0.1 \mathrm{ml}$ each of crude PTA or buffer, normal plasma and "cephalin"-calcium mixture. The PTA was prepared from Hageman factor-deficient plasma and was at its original concentration in plasma. Clotting times were measured in duplicate at $37^{\circ} \mathrm{C}$ in silicone-coated tubes.
VI. The effect of crude activated Hageman factor upon plasma thromboplastin antecedent. When crude preparations of activated Hageman factor and of PTA were incubated together, clotpromoting activity developed. The experiments to be described suggest that in this reaction the clot-promoting activity evolved from the action of activated Hageman factor upon PTA.

Crude preparations of activated Hageman factor and of PTA were incubated in silicone-coated tubes at $37^{\circ} \mathrm{C}$. At intervals, aliquots were added to a substrate of plasma deficient in PTA, and the clotting time of the mixture was measured in silicone-coated tubes. This experimental design was chosen to allow the study of any interreaction of activated Hageman factor and PTA without confusion by their effect upon the substrate plasma. Thus, PTA was furnished in the incubation mixture but not in the substrate. Hageman factor was present both in the incubation mixture and in the substrate. However, the crude Hageman factor in the incubation mixture had been "ac-

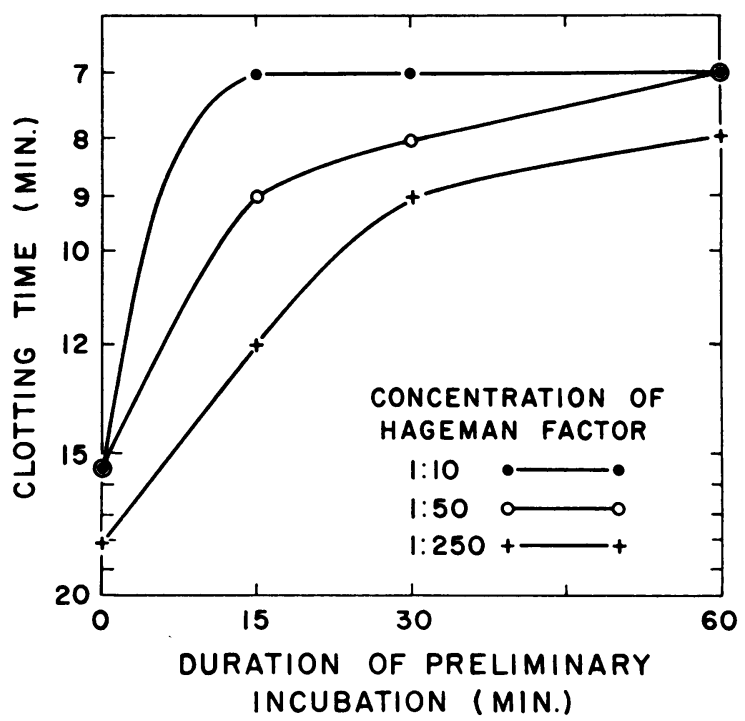

Fig. 2. The eVolution of ClOt-PROMOtING ACtivity IN MIXTURES OF CRUde ACTIVATEd Hageman FACTOR AND PTA. The influence of Concentration of Hageman FACTOR. Clotting time of a mixture of $0.1 \mathrm{ml}$ each of crude activated Hageman factor diluted serially with buffer, crude PTA diluted 1:4, PTA-deficient plasma and "cephalin"-calcium mixture. The activated Hageman factor and PTA were incubated for the indicated intervals prior to the addition of plasma and "cephalin"calcium mixture. Clotting times were determined in duplicate in silicone-coated tubes at $37^{\circ} \mathrm{C}$. 
tivated" during its preparation while that in the substrate plasma was presumably largely inactive, since this had not had contact with glass. Qualitatively similar results were obtained in experiments in which normal plasma was used as a substrate, but quantitative measurement was much more difficult.

When activated Hageman factor was incubated with PTA in silicone-coated tubes, potent clotpromoting activity evolved. The rate at which clot-promoting activity developed was determined by the concentration of crude Hageman factor in the mixture (Figure 2). At the highest concentration of activated Hageman factor tested, clot-promoting activity was maximal within 15 minutes after this substance was mixed wtih PTA. With lesser concentrations of activated Hageman factor, clot-promoting activity developed at a slower rate but, ultimately, essentially the same clot-promoting activity evolved regardless of the concentration of Hageman factor tested.

On the other hand, the magnitude of the clotpromoting activity which evolved was a function of the concentration of PTA in the mixture (Figure 3). In this experiment, an amount of activated Hageman factor sufficient to give a maximal

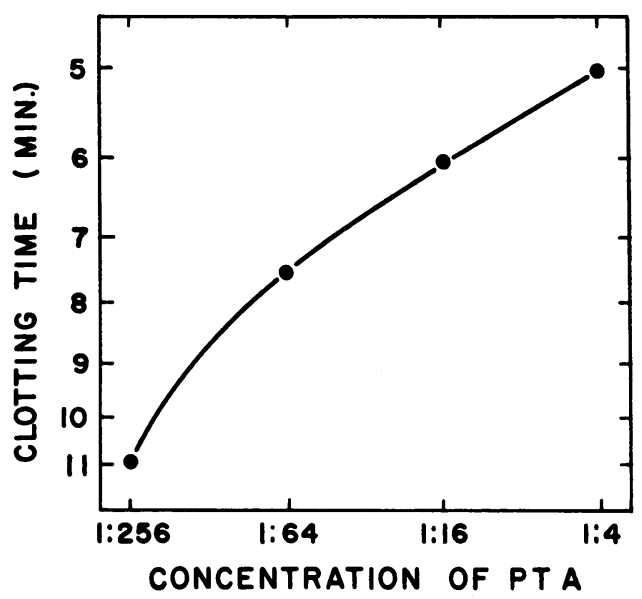

Fig. 3. The evolution of Clot-PRomoting activity IN MiXTURES OF CRUde ACTIVATED HAgeman FACTOR AND PTA. The influence of CONCENTRATION OF PTA. Clotting time of a mixture of $0.1 \mathrm{ml}$ each of crude activated Hageman factor diluted 1:10, crude PTA diluted serially with buffer, PTA-deficient plasma and "cephalin"calcium mixture. The activated Hageman factor and PTA were incubated at $37^{\circ} \mathrm{C}$ for 60 minutes prior to the addition of plasma and "cephalin"-calcium mixture. Clotting times were determined in duplicate at $37^{\circ} \mathrm{C}$.
TABLE VII

The spontaneous appearance of clot-promoting activity in preparations of plasma thromboplastin antecedent

\begin{tabular}{lccc}
\hline \multirow{2}{*}{ Test mixture } & \multicolumn{3}{c}{ Clotting time* (min) } \\
\cline { 2 - 4 } & At $\mathbf{0}$ hrs & $\begin{array}{c}\text { After } \\
\text { 24 hrs }\end{array}$ & $\begin{array}{c}\text { After } \\
\mathbf{4 8} \text { hrs }\end{array}$ \\
\hline PTA incubated at $4{ }^{\circ} \mathrm{C}$ & 23 & 15 & 22 \\
PTA incubated at $25^{\circ} \mathrm{C}$ & & 11 & 13 \\
PTA incubated at $37^{\circ} \mathrm{C}$ & 16 & 8 & 9 \\
Buffer control & 16 & 17 & 18
\end{tabular}

* Clotting time of a mixture of $0.1 \mathrm{ml}$ each of crude PTA or buffer, normal plasma and "cephalin"-calcium mixture. Five-tenths $\mathrm{ml}$ portions of freshly prepared PTA (prepared from Hageman factor-deficient plasma) were incubated in silicone-coated tubes at $4^{\circ}, 25^{\circ}$ or $37^{\circ} \mathrm{C}$ and aliquots were removed for testing at 0,24 , and 48 hours. Clotting times were measured in duplicate at $37^{\circ} \mathrm{C}$ in silicone-coated tubes.

effect within 15 minutes was incubated for 60 minutes with different amounts of PTA. In this way, conditions were arranged so that clot-promoting activity was assayed only after it had reached full development. Under these circumstances, clotpromoting activity developed in relation to the concentration of PTA.

The evolution of clot-promoting activity in a mixture of crude activated Hageman factor and crude PTA was not inhibited by the presence of $0.01 \mathrm{M}$ trisodium ethylenediamine tetraacetic acid, $0.15 \mathrm{M} \epsilon$-amino- $n$-caproic acid, $0.01 \mathrm{M}$ benzoyl-Larginine methyl ester, or soybean trypsin inhibitor in a concentration of $0.5 \mathrm{mg}$ per $\mathrm{ml}$. However, clot-promoting activity did not develop in the presence of $1 \mathrm{M} \mathrm{NaCl}$.

VII. The appearance of clot-promoting activity in crude preparations of plasma thromboplastin antecedent. That PTA may be converted into a clot-promoting substance was unexpectedly corroborated in studies of crude PTA prepared from plasma deficient in Hageman factor. Under certain conditions, clot-promoting activity arose spontaneously in preparations of crude PTA; this activity could not be distinguished from that which appeared when crude Hageman factor and PTA were incubated together.

Crude PTA was incubated in silicone-coated tubes in the presence of toluene vapor. At the start, and 24 and 48 hours later, the fraction was tested for clot-promoting activity (Table VII). Prior to incubation the fraction delayed the "cephalin"-fortified clotting time of normal plasma. 
After incubation at $37^{\circ} \mathrm{C}$ for 24 hours, the same fraction shortened the clotting time; no further activity developed in 48 hours. Another sample, incubated at $25^{\circ} \mathrm{C}$, had a lesser clot-promoting effect, and a third sample, incubated at $4^{\circ} \mathrm{C}$, was virtually unchanged.

The "spontaneous" appearance of clot-promoting activity in crude preparations of PTA was erratic, and the factors responsible for its development could not be clarified. In contrast to that which developed when PTA was incubated with crude activated Hageman factor, clot-promoting activity never appeared in less than 8 hours. Spontaneous clot-promoting activity developed in preparations of PTA derived from each of the five patients studied who had Hageman trait. Activity was more likely to appear when the fraction was dissolved in a volume of buffer equal to that of the plasma from which it was prepared; little or no activity evolved when the fraction was diluted further. Although activity evolved more consistently at $37^{\circ} \mathrm{C}$, storage of the fraction at temperatures as low as $-25^{\circ} \mathrm{C}$ did not always prevent its appearance within a few weeks. In several experiments, attempts were made to concentrate crude PTA by precipitation with ammonium sulfate at 55 per cent saturation followed by dialysis against buffer. Nearly always, clotpromoting activity appeared in these fractions, although the stage of preparation at which it developed could not be distinguished. Clot-promoting activity also appeared when crude PTA was adsorbed onto calcium phosphate gel and then eluted.

VIII. Evidence that the spontaneous clot-promoting activity of PTA preparations was not due to the action of activated Hageman Factor. The clot-promoting activity that appeared "spontaneously" in preparations of crude PTA accelerated the clotting not only of normal plasma but also of plasma obtained from patients with Hageman trait or PTA-deficiency (Table VIII). However, several lines of evidence indicate that this clotpromoting activity was probably not due to contamination of the crude PTA with Hageman factor. PTA was adsorbed more readily than Hageman factor by concentrated aluminum hydroxide gel (Section IV); a sample of Hageman factordeficient plasma, adsorbed with diluted aluminum hydroxide gel, had PTA activity, but the same
TABLE VIII

The clot-promoting effect of spontaneously activated plasma thromboplastin antecedent

\begin{tabular}{cccc}
\hline & \multicolumn{3}{c}{ Clotting time* (min) } \\
\cline { 2 - 4 } \multicolumn{1}{c}{ Test mixture } & $\begin{array}{c}\text { Hageman } \\
\text { factor- } \\
\text { plasma } \\
\text { deficient } \\
\text { plasma }\end{array}$ & $\begin{array}{c}\text { PTA-deficient } \\
\text { plasma }\end{array}$ \\
\hline $\begin{array}{l}\text { Spontaneously activated PTA } \\
\text { Buffer control }\end{array}$ & $\mathbf{8}$ & 7 & $\mathbf{7}$ \\
\hline
\end{tabular}

* Clotting time of a mixture of $0.1 \mathrm{ml}$ spontaneously activated crude PTA (prepared from "Hageman factor-deficient plasma) or buffer. ured in duplicate at $37^{\circ} \mathrm{C}$ in silicone-coated tubes.

plasma, adsorbed with concentrated aluminum hydroxide gel, lacked PTA activity.

The removal of PTA from plasma deficient in Hageman factor simultaneously removed its capacity to generate clot-promoting activity. In one experiment, Hageman factor-deficient plasma was adsorbed twice with concentrated aluminum hydroxide gel; it no longer contained detectable PTA, as measured by its capacity to shorten the clotting time of PTA-deficient plasma. This adsorbed plasma was heated at $56^{\circ} \mathrm{C}$ for 30 minutes and adsorbed with carboxymethylcellulose in the usual way. The eluate of the carboxymethylcellulose was incubated in silicone-coated tubes at $37^{\circ} \mathrm{C}$ for 91 hours. At the end of this time, it contained only about 2 per cent of the clot-promoting activity of an eluate prepared from the same plasma that had been adsorbed with dilute rather than concentrated aluminum hydroxide gel.

The clot-promoting activity which appeared in crude PTA was differentiated from Hageman factor by a second method. Spontaneously active PTA was qualitatively different from crude activated Hageman factor. It will be recalled that the clotting time of normal plasma was shortened by preliminary incubation with activated Hageman factor (Table II, column A). Under the same conditions, preliminary incubation with normal plasma did not increase the clot-promoting properties of spontaneously active PTA (column B).

In still another experiment, a preparation of crude activated Hageman factor was diluted until its clot-promoting activity for normal plasma was equal to that of a "spontaneously" active preparation of crude PTA. A mixture of activated Hageman factor and freshly prepared, inactive PTA was incubated at $37^{\circ} \mathrm{C}$ for 80 minutes. At the 
TABLE IX

The effect of activated Hageman factor and of spontaneously activated plasma thromboplastin antecedent upon inactive PTA

\begin{tabular}{lc}
\hline \multicolumn{1}{c}{ Test mixture } & $\begin{array}{c}\text { Clotting } \\
\text { time* }\end{array}$ \\
\hline Inactive PTA, $0.1 \mathrm{ml}+$ buffer, $0.1 \mathrm{ml}$ & $\min$ \\
Active PTA, $0.1 \mathrm{ml}+$ buffer, $0.1 \mathrm{ml}$ & 19 \\
$\begin{array}{c}\text { Activated Hageman factor, } 0.1 \mathrm{ml}+\text { buffer, } \\
0.1 \mathrm{ml}\end{array}$ & 11 \\
$\begin{array}{l}\text { Inactive PTA, } 0.1 \mathrm{ml}+\text { active PTA, } 0.1 \mathrm{ml} \\
\text { Inactive PTA, } 0.1 \mathrm{ml}+\text { activated Hageman } \\
\text { factor, 0.1 ml }\end{array}$ & 12 \\
Buffer control, $0.2 \mathrm{ml}$ & 7 \\
\hline
\end{tabular}

* Clotting time of $0.2 \mathrm{ml}$ test mixture, $0.1 \mathrm{ml}$ normal plasma and $0.1 \mathrm{ml}$ "cephalin"-calcium mixture. The test mixtures were incubated in silicone-coated tubes for 80 minutes at $37^{\circ} \mathrm{C}$ prior to the addition of plasma and "cephalin"-calcium. Clotting times were measured in duplicate at $37^{\circ} \mathrm{C}$.

end of this period, further clot-promoting activity had evolved in the mixture (Table IX). On the other hand, no additional clot-promoting activity appeared in a mixture of "spontaneously active" and inactive PTA incubated for the same period. Again, spontaneously active PTA did not behave like activated Hageman factor in its effect upon inactive PTA.

IX. Some properties of the clot-promoting activity evolving in crude plasma thromboplastin antecedent "spontaneously" or upon treatment with activated Hageman factor. The clot-promoting activity which appeared when crude PTA was treated with activated Hageman factor could not be distinguished from that which evolved "spontaneously." In preparations that seemed to be fully activated, the clot-promoting activity was striking. Either preparation, diluted 300 -fold or more compared with the plasma from which it was prepared, significantly accelerated the "cephalin"-fortified clotting time of an equal volume of normal plasma.

The clot-promoting activity could not be identified with that of other known clotting factors. Neither preparation was thrombin-like, for they did not clot bovine fibrinogen, even in the presence of calcium ions. Nor did they contain prothrombin, proaccelerin, pro-SPCA, Stuart factor or antihemophilic factor, as tested by specific assays for each of these substances. They either were without corrective effect upon plasma deficient in Christmas factor, or shortened its recalcified clotting time or partial thromboplastin time insignificantly; in one experiment, the partial thromboplastin time of plasma deficient in Christmas factor was shortened from 653 to 553 seconds by a preparation of PTA activated by Hageman factor. The partial thromboplastin time of normal plasma, tested by this method, is usually less than 100 seconds.

By inference, the clot-promoting property appeared to function early in the clotting process. It altered neither the thrombin time nor the prothrombin time of normal plasma. However, it significantly increased prothrombin "consumption" in whole blood. Typical data, obtained with a "spontaneously" active PTA preparation, are recorded in Table X. These experiments are compatible with the view that the clot-promoting substance evolved from preparations of PTA acts early in the clotting process.

The clot-promoting agent which developed when PTA was treated with Hageman factor did not digest $p$-toluenesulfonyl-L-arginine-methyl ester, distinguishing its action from that of thrombin, plasmin and the esterase derived from the first component of complement.

$X$. The inhibition of activated Hageman factor and "activated" plasma thromboplastin antecedent by plasma. The clot-promoting activity which appears when normal plasma is exposed to glass gradually deteriorates (30). This decrease in activity has been attributed to the presence of an inhibitory substance that may have enzymatic properties (2). The specificity of the inhibition with regard to activated Hageman factor or activated plasma thromboplastin is not certain.

TABLE $\mathrm{X}$

The effect of spontaneously activated plasma thromboplastin antecedent upon serum prothrombic activity

\begin{tabular}{cc}
\hline \hline Test substance & $\begin{array}{c}\text { Prothrombic } \\
\text { activity* }\end{array}$ \\
\hline & $\%$ \\
Inactive PTA & 50 \\
Spontaneously active PTA & 10 \\
Buffer control & 50
\end{tabular}

* Serum prothrombic activity of a mixture of $0.2 \mathrm{ml}$ of undiluted inactive or spontaneously active PTA or buffer and $2.05 \mathrm{ml}$ whole blood, incubated at $37^{\circ} \mathrm{C}$ for 1 hour in Pyrex tubes. The PTA was prepared from Hageman factor-deficient plasma. 
A fraction of plasma was prepared which inhibited the clot-promoting activity of glass-treated plasma. This fraction was incubated with crude activated Hageman factor and with "spontaneously" activated PTA. In each case, the clotpromoting activity was decreased (Table XI). Whether the same principle inactivated Hageman factor and "spontaneously" activated PTA was not ascertained. Additional studies to confirm the enzymatic nature of the inhibitory substance were not performed, but its activity was not diminished by incubation with diisopropyl fluorophosphate at a concentration of $5 \times 10^{-4} \mathrm{M}, 0.05 \mathrm{mg}$ soybean trypsin inhibitor per $\mathrm{ml}, 0.001 \mathrm{~N}$ mercuric chloride, $0.0125 \mathrm{~N}$ hydrogen peroxide, or $0.01 \mathrm{M}$ trisodium ethylenediamine tetraacetic acid.

$X I$. The effect of diisopropyl fuorophosphate upon Hageman factor, plasma thromboplastin antecedent and activated plasma thromboplastin antecedent. Becker (31) observed that diisopropyl fluorophosphate inhibited the clot-promoting properties of Hageman factor. However, the preparation which he used undoubtedly contained PTA in addition to Hageman factor, and his method of assay did not distinguish between these factors. Crude activated Hageman factor, devoid of PTA, was incubated with DFP at a concentration of $5 \times 10^{-4} \mathrm{M}$ for 1 hour and then dialyzed against repeated changes of buffer. Similarly, crude PTA, devoid of Hageman factor, and PTA, activated "spontaneously" or by incubation with activated Hageman factor, were treated with DFP.

TABI,E XI

The effect of an inhibitory fraction of plasma upon activated Hageman factor and spontaneously activated plasma thromboplastin antecedont

\begin{tabular}{cc}
\hline Test mixture & $\begin{array}{c}\text { Clotting } \\
\text { time* }\end{array}$ \\
\hline $\begin{array}{l}\text { Activated Hageman factor, } 0.1 \mathrm{ml} \text { +inhibitor, } 0.1 \mathrm{ml}, \\
\text { separately incubated, then mixed }\end{array}$ & $\min$ \\
$\begin{array}{c}\text { Activated Hageman factor, } 0.1 \mathrm{ml} \text { +inhibitor, } 0.1 \mathrm{ml}, \\
\text { incubated together }\end{array}$ & 13 \\
$\begin{array}{c}\text { Activated PTA, 0.1 ml +inhibitor, } 0.1 \mathrm{ml} \text {, separately } \\
\text { incubated, then mixed }\end{array}$ & 11 \\
$\begin{array}{c}\text { Activated PTA, } 0.1 \mathrm{ml}+\text { inhibitor, } 0.1 \mathrm{ml} \text {, incubated } \\
\text { together }\end{array}$ & 19 \\
$\begin{array}{l}\text { Buffer, } 0.1 \mathrm{ml}+\text { inhibitor, } 0.1 \mathrm{ml} \\
\text { Buffer, } 0.2 \mathrm{ml}\end{array}$ & 18 \\
\end{tabular}

* Clotting time of a mixture of $0.2 \mathrm{ml}$ of the test mixture, $0.1 \mathrm{ml}$ of normal plasma and $0.1 \mathrm{ml}$ of "cephalin"-calcium mixture. The tes mixture was composed of crude activated Hageman factor (diluted 1:10) or crude spontaneously activated PTA, mixed with an inhibitory fraction of plasma. These substances were incubated either together or separately and then combined. This incubation and the clotting
times were performed in duplicate at $37^{\circ} \mathrm{C}$ in silicone-coated tubes.
TABLE XII

The effect of diisopropyl fluorophosphate upon activated Hageman factor and activated plasma thromboplastin antecedent

\begin{tabular}{lcc}
\hline & \multicolumn{2}{c}{ Clotting time* } \\
\cline { 2 - 3 } \multicolumn{1}{c}{ Test mixture } & $\begin{array}{c}\text { Hageman } \\
\text { factor- } \\
\text { deficient } \\
\text { plasma }\end{array}$ & $\begin{array}{c}\text { PTA-deficient } \\
\text { plasma }\end{array}$ \\
\hline $\begin{array}{l}\text { Untreated activated PTA } \\
\begin{array}{l}\text { DFP-treated activated PTA } \\
\text { Untreated activated Hageman factor }\end{array}\end{array}$ & min \\
$\begin{array}{l}\text { DFP-treated activated Hageman factor } \\
\text { Buffer control }\end{array}$ & 14 & 11 \\
\hline
\end{tabular}

* Clotting time of a mixture of $0.1 \mathrm{ml}$ each of crude activated Hageman factor or PTA (each diluted 1:10), plasma and $0.025 \mathrm{M}$ calciu chloride. The clotting times were measured in duplicate in Pyrex

Treated and untreated fractions were then tested for their specific corrective effect for deficient plasmas, and for their nonspecific clot-promoting activity for normal plasma.

Crude activated Hageman factor, devoid of PTA, regularly lost three-fourths or more of its clot-promoting activity for both normal plasma and plasma deficient in Hageman factor after treatment with DFP (Table X). In contrast, when normal plasma was incubated for 1 hour with DFP and then dialyzed against buffer, none of its Hageman factor-like activity was lost, and clotpromoting activity appeared when it was agitated with crushed glass. In normal plasma, Hageman factor behaves as if it were inactive, until it is exposed to glass or similar substances. One may infer that DFP inhibits activated Hageman factor but not its inactive precursor.

Similarly, crude PTA was unaffected by incubation with DFP. However, "spontaneously" active PTA, or PTA activated by Hageman factor, was sensitive to DFP, losing about threefourths of its activity under the conditions at which it was tested (Table XII).

DISCUSSION

Almost 100 years ago, Lister (32) observed that the coagulation of mammalian blood was enhanced by contact with a foreign surface. Normal blood-liquid within the blood vessels-clots within a few minutes in a glass tube. The mechanisms through which glass and other clot-promoting surfaces act have been studied persistently. Until recently, attention was centered upon the effect of these agents on the formed elements of 
the blood. However, a profusion of experiments, beginning with those of Bordet and Gengou (33), demonstrated that glass and certain other substances can initiate or accelerate clotting in plasma depleted of its cells. One site of action of glass is Hageman factor, present in normal plasma but lacking in the plasma of patients with Hageman trait $(2-8)$. Perhaps other factors are altered as well $(7,34)$; it is difficult to distinguish between a direct effect of glass upon a clotting factor and an indirect effect mediated through its activation of Hageman factor.

Currently, the most satisfactory hypothesis to explain the effect of glass upon Hageman factor relates to its adsorbent properties. Clotting is accelerated by many other adsorbents including kaolin (2), barium carbonate $(2,35)$, charcoal (2), Supercel (2), Celite (5), bentonite (36), asbestos (8) and silicic acid (37), and, as demonstrated in the present study, carboxymethylcellulose. Like glass, these adsorbents are effective only when the plasma tested contains Hageman factor. These considerations have led to the view that the clot-promoting properties of glass and other adsorbents depend upon their capacity to adsorb Hageman factor, which changes from an inactive to an active form in the process.

The molecular rearrangements that result in the activation of Hageman factor are unknown. Fiala (35) thought that glass or barium carbonate initiated clotting by removing an inhibitor from plasma. We have been unable to isolate an inhibitor from untreated normal plasma. However, plasma deficient in Hageman factor inhibits the clot-promoting effects of glass, barium carbonate and asbestos $(2,29)$. This inhibitory activity appears to be clirected against the activation of Hageman factor. Minute amounts of preparations containing active Hageman factor shorten the clotting time of plasma deficient in this substance (1) (Table I). Attractive as it may be to imagine that the same inhibitory activity exists in normal plasma, masked by the presence of Hageman factor, this view is unproved. Similar inhilitory activity can be demonstrated in normal plasma heated at $60^{\circ} \mathrm{C}$ to destroy the Hageman factor it contains, but these results may well be artifactual (38). Dissenting views, that the inhibitory activity in Hageman factor-deficient plasma is "nonspecific" (10) or is the essential defect in Hageman trait (11), are equally conjectural.

Once it has been activated, Hageman factor apparently accelerates the coagulation of normal blood or plasma (Table II). Previous studies to cletermine how this acceleration comes about were handicapped because preparations of Hageman factor of adequate purity were not available. Our earlier attempts to purify Hageman factor from normal serum $(2,39)$ were vitiated by unsuspected contamination with plasma thromboplastin antecedent (12). Nonetheless, several groups of investigators have proposed that Hageman factor, once activated by glass, reacts with a second clotting factor, PTA, to produce a clot-promoting substance variously called activation product (5), the third prothromboplastic factor (11), antihemophilic factor C (11) or activated PTA (10). Hardisty and Margolis (10) conceived that active Hageman factor serves as a catalyst to convert PTA from an inactive to an active form, but they did not provide direct supporting evidence. They believed that Hageman factor exerts its effect upon PTA only while both are adsorbed to glass or other surfaces. In their view, the activated PTA then returns to solution to initiate further stages in the clotting process. All agree that calcium ions are not required for the activation of Hageman factor by glass, but Soulier and Prou-Wartelle (36) thought that calcium might be needed for the interaction of Hageman factor and PTA.

Some clarification of the function of activated Hageman factor and its relationship to PTA has been possible, using the relatively simple techniques described in the present report. A crude fraction, rich in activated Hageman factor and apparently deficient in other known clotting factors, was prepared from plasma believed $c_{2}$ eficient in PTA. In the same way, a crude fraction containing PTA was prepared from plasma deficient in Hageman factor. Hageman factor, prepared by this method, was apparently purified about 100 -fold and in the process was activated, for now it accelerated the clotting of normal blood or plasma; whether all or only part of the Hageman factor was activated is not yet clear. The fraction corrected the coagulative defect of plasma deficient in Hageman factor but had no effect upon the clotting time of plasma deficient in PTA. Its effect on normal blood seemed to be localized to an early stage of 
clotting, in keeping with earlier premises that the defect in Hageman factor-deficient plasma is in the initiation of blood coagulation and that Hageman factor is needed for the evolution of thromboplastic activity in shed blood (1).

Experiments in which crude activated Hageman factor was incubated with normal citrated plasma in silicone-coated tubes demonstrated that this factor reacted with some component of the plasma in the absence of calcium ions. However, they provided no clues concerning the component with which activated Hageman factor reacted.

When crude activated Hageman factor was incubated with crude PTA, clot-promoting activity of considerable potency gradually evolved. Kinetic experiments demonstrated that the extent of this activity was related to the concentration of PTA in the mixture, while the rate at which it developed depended upon the concentration of activated Hageman factor. Our present interpretation of these studies is that Hageman factor is an enzyme whose substrate, PTA, is converted to an active clot-promoting agent, tentatively designated as activated PTA. This reaction occurred when solutions of activated Hageman factor and PTA were incubated in silicone-coated tubes; the presence of a glass-like surface did not seem necessary. The reaction took place in the presence of appreciable quantities of trisodium ethylenediamine tetraacetic acid and thus did not seem to be calciumdependent. Thus, the initial phases of blood coagulation may be schematized as in Figure 4 .

Nothing in these experiments rules out the possibility that other as yet unidentified agents, pres-

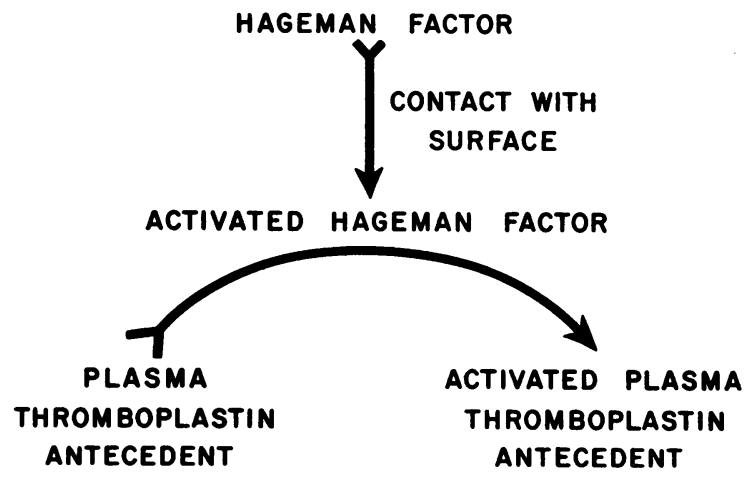

Fig. 4. A tentative SCheme outlining the initial STEPS in the COAGUlation of PLASMa. Modified from Reference 47. ent in the crude preparations of Hageman factor and PTA, are needed for the development of clotpromoting activity. Indeed, these fractions may well contain other clot-accelerating substances, which may function in ways not detected by our present techniques. A wealth of previous experience cautions against the assumption that "purified" clotting factors are free of other clot-accelerating materials.

The enzymatic nature of activated Hageman factor is supported by its inhibition by diisopropyl fluorophosphate, first demonstrated by Becker (31) and now confirmed with purer preparations of activated Hageman factor. Likewise, the reaction of activated PTA with DFP supports the conclusion that it also is an enzyme. In contrast, Hageman factor and PTA are not affected by DFP. Thus, these reactions are analagous to those of trypsinogen and trypsin (40-42), chymotrypsinogen and chymotrypsin (40), plasminogen and plasmin (43), and prothrombin and thrombin $(44,45)$. In each of these cases, the enzyme precursors are unaffected by organophosphorous compounds, while the active form is rapidly inhibited. Whether activated Hageman factor and activated PTA preparations will show similar $\mathrm{pH}$ dependency as well as the direct binding of the diisopropyl phosphoryl moiety to a serine residue remains to be investigated. Neither activated Hageman factor nor activated PTA was totally inactivated by DFP. This probably reflects the presence in the crude preparations tested of other, unidentified clot-promoting substances which are DFP-resistant.

Activated Hageman factor may well have natural substrates other than PTA. Margolis (46, 47) has implicated this substance in the activation of "pain-producing factor" and "capillary permeability factor" of normal serum. However, a search for protein or synthetic substrates of activated Hageman factor, only partly recorded here, has been unrewarding.

Information has also been provided concerning the properties of PTA. The crude preparations we have made represent an apparent purification of this substance of only about 10 - to 20 -fold. In its inactive form it had no effect upon the coagulation of normal plasma or plasma deficient in Hageman factor. Once treated by activated Hageman factor, it accelerated the coagulation of both 
of these plasmas. Again, its action seemed limited to the earliest steps of coagulation, the formation of thromboplastic activity. Presumably, activated Hageman factor affected this stage of coagulation by activating PTA, and this in turn initiated the steps leading to the conversion of prothrombin to thrombin. In these reactions, activated PTA may well have enzymatic activity; its inhibition by diisopropyl fluorophosphate is compatible with this view. However, its substrate has not been delineated. Preliminary experiments, not reported here, suggest that Christmas factor may be a substrate, but data to establish this are not yet available. Calcium ions may be needed for the action of activated PTA on its substrate, but again satisfactory experimental data are not yet at hand.

A perplexing question has been the dearth of hemorrhagic symptoms in persons whose plasma apparently lacks Hageman factor $(1,12)$. Some insight into this problem may have been gained from studies of "spontaneously" active PTA. Crude PTA, purified by the method described, did not accelerate the coagulation of normal blood or plasma. However, such preparations, incubated alone at $37^{\circ} \mathrm{C}$, acquired clot-promoting activity that could not be distinguished from that which evolved in the presence of Hageman factor. By implication, some mechanisms permitting the activation of PTA at the site of an injury may be available to the patient with Hageman trait. How this might come about has not yet been studied.

The mechanism responsible for the spontaneous appearance of clot-promoting activity in crude preparations of PTA is unknown. Studies of this process have been hampered because as yet all of our attempts at further purification of PTA have produced activated products. As yet, there is no reason to believe that the activation process is autocatalytic and, indeed, the addition of activated PTA to its inactive precursor seemed without effect. Conceivably, the plasma from which the PTA was prepared, devoid of detectable Hageman factor by other measures, contained traces of this substance. Under appropriate conditions these traces of Hageman factor might activate PTA. Of course, other explanations must also be considered. Several groups have suggested that the plasma of patients with Hageman trait contains normal amounts of Hageman factor, blocked by the presence of an inhibitor. This assumption seems unwarranted, since the merest trace of normal plasma will shorten the clotting time of plasma from patients with Hageman trait.

The clot-promoting activity induced by treating normal plasma with glass is labile (30). The loss of clot-promoting activity is apparently related to the presence of one or more inhibitors. A crude concentrate of plasma, containing this inhibitory activity, seemed to inactivate both activated Hageman factor and spontaneously activated PTA. Whether this inhibitory activity is due to the presence of one or several substances is not yet clear. Further studies have been vitiated by the lability of the inhibitory activity during purification.

This discussion has purposely emphasized the large areas of uncertainty concerning the functions and properties of Hageman factor and PTA. It is hoped that these uncertainties will disappear when purer preparations of these factors become available. By taking advantage of the ease with which aluminum hydroxide adsorbs PTA we have made considerable progress in the purification of Hageman factor from normal plasma; our best preparations are now at least 1,000-fold purified, but the yields are poor. No such progress has been made in the purification of PTA; all attempts have been blocked by the spontaneous activation of this substance. As purer preparations become available, a more meaningful analysis of the successive steps in the coagulative process should become possible.

\section{SUMMARY}

Methods for the partial purification of Hageman factor and plasma thromboplastin antecedent, and some of the properties of these substances, are described. In the process of purification, Hageman factor seems to be converted from an inactive to an active form. When partially purified activated Hageman factor and plasma thromboplastin antecedent are incubated together, clot-promoting activity evolves. Studies suggest that plasma thromboplastin antecedent is converted during this procedure from an inactive to an active form by an enzymatic process. Under certain conditions, clot-promoting activity of an apparently identical nature appears spontaneously in preparations of plasma thromboplastin antecedent. Activated 
Hageman factor and activated plasma thromboplastin antecedent are inhibited by diisopropyl fluorophosphate and by a fraction of normal plasma.

These studies are in agreement with the hypothesis that activated Hageman factor initiates clotting by an enzymatic process. The data presented may help to explain the asymptomatic nature of Hageman trait.

\section{ACKNOWLEDGMENT}

These studies were made possible by the technical assistance of Miss Ann M. Harris and Mrs. Eugene Hussey. Drs. Robert Rosenthal, Irving Wright and Margaret Todd kindly permitted us to obtain blood samples from their patients with plasma thromboplastin antecedent deficiency, and Drs. Todd and Marjorie Zucker provided us with facilities in New York City to prepare some of this plasma.

\section{REFERENCES}

1. Ratnoff, O. D., and Colopy, J. E. A familial hemorrhagic trait associated with a deficiency of a clotpromoting fraction of plasma. J. clin. Invest. $1955,34,602$.

2. Ratnoff, O. D., and Rosenblum, J. M. Role of Hageman factor in the initiation of clotting by glass: Evidence that glass frees Hageman factor from inhibition. Amer. J. Med. 1958, 25, 160.

3. Biggs, R., Sharp, A. A., Margolis, J., Hardisty, R. M., Stewart, J., and Davidson, W. M. Defects in the early stages of blood coagulation: A report of 4 cases. Brit. J. Haemat. 1958, 4, 177.

4. Soulier, J.-P., Wartelle, O., and Ménaché, D. Hageman trait and PTA deficiency: The role of contact of blood with glass. Brit. J. Haemat. 1959, 5, 121.

5. Waaler, B. A. Contact activation in the intrinsic blood clotting system. Studies on a plasma product formed on contact with glass and similar surfaces. Scand. J. clin. Lab. Invest. 1959, 11, suppl. $37,1$.

6. Lewis, J. H., Walters, D., Didisheim, P., and Merchant, W. R. Application of continuous flow electrophoresis to the study of the blood coagulation proteins and the fibrinolytic enzyme system. I. Normal human materials. J. clin. Invest. 1958, 37, 1323.

7. Vroman, L. Surface contact and thromboplastin formation. Thesis, University of Utrecht, 1958.

8. Johnston, C. L., Jr., Ferguson, J. H., and O'Hanlon, F. A. Surface activation of plasma clotting: A function of Hageman factor. Prcc. Soc. exp. Biol. (N. Y.) 1958, 99, 197.

9. Margolis, J. Activation of plasma by contact with glass: Evidence for a common reaction which re- leases plasma kinin and initiates coagulation. J. Physiol. (Lond.) 1958, 144, 1.

10. Hardisty, R. M., and Margolis, J. The role of Hageman factor in the initiation of blood coagulation. Brit. J. Haemat. 1959, 5, 203.

11. Soulier, J. P., Wartelle, O., and Ménaché, D. Caractères différentiels des facteurs Hageman et PTA; rôle du contact dans la phase initiale de la coagulation. Rev. franç. Et. clin. biol. 1958, 3, 263.

12. Ratnoff, O. D. Hageman trait. Thromb. Diath. haemor. 1960, 4, suppl., 116.

13. Egli, H., and Buscha, H. Zur Differenzierung und Kalzium-Abhängigkeit von Kontaktwirkungen benetzbarer Oberflächen. Ihr Einfluss auf die Blutthrombokinase-Bildung. Thromb. Diath. haemor. 1959, 3, 604.

14. Ratnoff, O. D. Bleeding Syndromes: A Clinical Manual. Springfield, Ill., C. C Thomas, 1960.

15. Rosenthal, R. L., Dreskin, O. H., and Rosenthal, N. New hemophilia-like disease caused by deficiency of a third plasma thromboplastin factor. Proc. Soc. exp. Biol. (N. Y.) 1953, 82, 171.

16. Todd, M. E., Panter, G., and Wright, I. S. Deficiency of one or more factors of unusual interest. Thromb. Diath. haemor. 1960, 4, suppl. 151.

17. Rosenthal, R. L. Personal communication.

18. Conley, L. C., Hartman, R. C., and Morse, W. I., II. The clotting behavior of human "plateletfree" plasma: Evidence for the existence of a "plasma thromboplastin." J. clin. Invest. 1949, 28, 340.

19. Ellis, S., and Simpson, M. E. The chromatography of growth hormone on cellulose derivatives. J. biol. Chem. 1956, 220, 939.

20. Margolius, A., Jr., and Ratnoff, O. D. Observations on the hereditary nature of Hageman trait. Blood 1956, 11, 565.

21. Seibert, R. H., Margolius, A., Jr., and Ratnoff, O. D. Observations on hemophilia, parahemophilia, and coexistent hemophilia and parahemophilia. Alterations in platelets and thromboplastin generation test. J. Lab. clin. Med. 1958, 52, 449.

22. Alexander, B. Estimation of plasma prothrombin by the one-stage method in The Coagulation of Blood, Methods of Study, L. M. Tocantins, Ed. New York, Grune \& Stratton, 1955, p. 89.

23. Sise, H. S., Lavelle, S. M., and Becker, R. A method for assay of Stuart factor. Proc. Soc. exp. Biol. (N. Y.) 1957, 96, 662.

24. Quick, A. J., Stanley-Brown, M., and Bancroft, F. W. A study of the coagulation defect in hemophilia and jaundice. Amer. J. med. Sci. 1935, 190, 501.

25. Langdell, R. D., Wagner, R. H., and Brinkhous, K. M. Effect of antihemophilic factor on onestage clotting tests. A presumptive test for hemophilia and a simple one-stage antihemophilic factor assay procedure. J. Lab. clin. Med. 1953, 41, 637.

26. Bell, W. N., and Alton, H. G. A brain extract as a substitute for platelet suspensions in the thrombo- 
plastin generation test. Nature (Lond.) 1954, $174,880$.

27. Ratnoff, O. D., and Lepow, I. H. Some properties of an esterase derived from preparations of the first component of complement. J. exp. Med. 1957, 106, 327.

28. Lowry, O. H., Rosebrough, N. J., Farr, A. L., and Randall, R. J. Protein measurement with the Folin phenol reagent. J. biol. Chem. 1951, 193, 265.

29. Johnston, C. L., Jr., and Ferguson, J. H. Hageman factor activation and related processes in Hemophilia and Other Hemorrhagic States, K. M. Brinkhous and P. de Nicola, Eds. Chapel Hill, Univ. of N. C. Press, 1959, p. 192.

30. Margolis, J. Initiation of blood coagulation by glass and related surfaces. J. Physiol. (Lond.) 1957, 137, 95.

31. Becker, E. L. Inactivation of Hageman factor by diisopropyl fluorophosphate (DFP). J. Lab. clin. Med. 1960, 56, 136.

32. Lister, J. On the coagulation of the blood. Proc. roy. Soc. Med. 1862-63, 12, 580.

33. Bordet, J., and Gengou, O. Recherches sur la coagulation du sang et les sérums anticoagulants. Ann. Inst. Pasteur 1901, 15, 129.

34. Rapaport, S. I. Evidence that glass increases plasma PTA activity. J. Lab. clin. Med. 1958, 52, 624.

35. Fiala, S. On the role of a protein inhibitor in the first stage of blood coagulation. Arch. int. Physiol. 1951, 58, 386.

36. Soulier, J.-P., and Prou-Wartelle, O. New data on Hageman factor and plasma thromboplastin antecedent: The role of "contact" in the initial phase of blood coagulation. Brit. J. Haemat. 1960, 6, 88.
37. Didisheim, P. The activiation of Hageman factor by silicic acid. Fed. Proc. 1959, 18, 474.

38. Ratnoff, O. D., and Mallett, D. L. Unpublished observations.

39. Ratnoff, O. D., and Margolius, A., Jr. Hageman trait: An asymptomatic disorder of blood coagulation. Trans. Ass. Amer. Phycns 1955, 68, 149.

40. Jansen, E. F., Nutting, M. D. F., Jang, R., and Balls, A. K. Inhibition of the proteinase and esterase activities of trypsin and chymotrypsin by diisopropyl fluorophosphate: Crystallization of inhibited chymotrypsin. J. biol. Chem. 1949, 179, 189.

41. Tietze, F. Molecular-kinetic properties of crystalline trypsinogen. J. biol. Chem. 1953, 204, 1.

42. Cunningham, L. W., Jr. Molecular-kinetic properties of crystalline diisopropyl phosphoryl trypsin. J. biol. Chem. 1954, 211, 13.

43. Mounter, L. A., and Shipley, B. A. The inhibition of plasmin by toxic phosphorous compounds. J. biol. Chem. 1958, 231, 855.

44. Gladner, J. A., and Laki, K. Inhibition of thrombin by diisopropyl phosphofluoridate. Arch. Biochem. 1956, 62, 501.

45. Miller, K. D., and Van Vunakis, H. The effect of diisopropyl fluorophosphate on the proteinase and esterase activities of thrombin and on prothrombin and its activators. J. biol. Chem. 1956, 223, 227.

46. Margolis, J. Experiments on Hageman factor. Thromb. Diath. haemor. 1960, 4, suppl. 132.

47. Margolis, J. The role of Hageman factor in plasma/ surface reactions in Hemophilia and Other Hemorrhagic States, K. M. Brinkhous and P. de Nicola, Eds. Chapel Hill, Univ. of N. C. Press, 1959, p. 208. 